\title{
On the Model of Public Entitties Participation in Civil Relations in Terms of the Legal Positions of the Constitutional Court of the Russian Federation
}

\author{
Inna S. Bogdanova* \\ Siberian Federal University \\ Krasnoyarsk, Russian Federation
}

Received 22.07.2020, received in revised form 31.08.2020, accepted 29.09.2020

\begin{abstract}
The article is devoted to the problem of changing the model of participation of public legal entities in civil relations. This change is to be made by the Constitutional Court of the Russian Federation on the example of non-contractual obligations between the state and individuals. For this purpose there was made a study of legislative model of state participation in private relations, as stipulated in Articles 2 and 125 of the Civil Code of the Russian Federation, and legal positions of the Constitutional Court of the Russian Federation, enlisted in the Resolutions of the Constitutional Court of the Russian Federation No. 16-P dated 22.06.2017 and No. 39-P dated 08.12.2017. As a result, the author concludes that the current legal model of participation of public legal entities in civil relations does not provide any exceptions for non-contractual obligations between the state and individuals. On the contrary, the legislators are consistent in addressing the issue of which state bodies are able to ensure the civil legal capacity of the individuals and under what conditions. Amendment of the above model by the Constitutional Court of the Russian Federation via expanding the list of bodies capable of creating legal consequences for public entities, without taking into account the scope of their competence, as well as differences between federal bodies and bodies of state power of the subjects of the Russian Federation, is considered untimely, since the matter requires further thorough study and elaboration.
\end{abstract}

Keywords: public legal entity, government body, state authority, civil legal capacity of the state, model of participation, civil relations, registration authority, tax body.

Research area: law.

Citation: Bogdanova, I.S. (2020). On the model of public entitties participation in civil relations in terms of the legal positions of the Constitutional Court of the Russian Federation. J. Sib. Fed. Univ. Humanit. Soc. Sci., 13(10), 1679-1686. DOI: 10.17516/1997-1370-0674.

(C) Siberian Federal University. All rights reserved

* Corresponding author E-mail address: bogdanov_rabota@mail.ru ORCID: 0000-0003-0732-2929 


\section{Introduction}

The current Civil Code of the Russian Federation sets forth general provisions on the participation of state and other public legal entities in civil legal relations. However, over the last three years the Constitutional Court of the Russian Federation has formed such legal positions that differ from the legal provisions, which predetermined the necessity of their analysis and interpretation. The Constitutional Court of the Russian Federation actually proposed a new solution to the problem concerning the model of participation of public legal entities in civil relations on the example of non-contractual obligations with individuals.

\section{Research description}

The general rules on the model of participation of public entities in civil relations are itemized in Articles 2, 124 and 125 of the Civil Code of the Russian Federation (hereinafter referred to as the Civil Code). In general, the Russian legislation has accepted the idea of recognizing public entities as independent subjects of private relations along with individuals and legal entities participating in these relations through the actions of their bodies. At the same time, the legislators have clearly defined the criteria for qualifying government authorities for implementing the legal capacity of the Russian Federation and the subjects of the Russian Federation in the relations regulated by civil legislation.

The procedure for the participation of public entities in relations governed by civil law is directly specified by Art. 125 of the Civil Code, with two different rules set out in Items 1 and 3 of this Article. Thus, by virtue of paragraph 2 Item 1 Article 2 of the Civil Code, the participants of relations governed by civil law are citizens and legal entities. The Russian Federation, the subjects of the Russian Federation and municipal entities may also participate in these relations. In this case the legislators used the wording "may participate" in counterbalance to the expression "are participants" in relation to natural persons and legal entities, which is not incidental. The reason is that state is not so active as individuals and legal entities in such relations; the role played by the state in the life of society does not imply its active involvement, on the contrary, participation in private relations for state authorities is rather an exception in special cases when the norms of the Civil Code shall be applied for the regulation of the relations. Such situations comprise non-contractual obligations, including those resulting from vindication requirements and infliction of harm.

According to Item 1 Art. 125 of the Civil Code of the Russian Federation, government bodies have the right to act on behalf of public entities: they may acquire and exercise property and personal non-property rights and obligations, appear in court within their competence, established by acts determining the status of these bodies. The above provision presumes that only state authorities may act directly on behalf of public entities, and the right of the body to act on behalf of the state must be provided for in the act defining its status and must comply with its competence.

Unlike Item 1, Item 3 of Art. 125 of the Civil Code gives a different wording: in cases and in the manner prescribed by regulatory legal acts concerning public entities (federal laws, decrees of the President of the Russian Federation, decrees of the Government of the Russian Federation, regulatory acts of the subjects of the Russian Federation) government bodies, as well as legal entities and individual citizens can act for and on the behalf of the public entities. This means that in order to participate in civil relations on behalf of public entities other than those specified in Item 1 of Art. 125 of the Civil Code of the Russian Federation, their representative must meet a number of conditions, namely, 1) the cases and order of such representation shall be fixed in regulatory acts; 2) there shall be a special assignment made in respect of these government bodies, legal entities and individuals.

Hence, in accordance with Item 1 of Art. 125 of the Civil Code of the Russian Federation, as a general rule, the participation of the Russian Federation and the subjects of the Russian Federation in civil relations is carried out through the actions of state authorities, and in special cases (defined in Item 3 of Art. 125 of the Civil Code), if there is a special assignment, 
other subjects (government bodies, legal entities and individual citizens) can act on behalf of public entities.

As it follows from the aforesaid, Article 125 of the Civil Code of the Russian Federation uses various terms to designate civil capacity of the Russian Federation and its subjects in civil relations: "government bodies" 2 (Item 1 of Art. 125 of the Civil Code) and "state authorities" (Item 3 of Art. 125 of the Civil Code). This circumstance, in our opinion, is of fundamental importance for the solution of the problem of the legislative model characterising state participation in civil relations.

The common feature of the concepts "government bodies" and "state authorities" is their belonging to the category of bodies/agencies, typifying the structural unit of the state apparatus. As such, they possess an array of distinctive features: 1) the body is a part of the state apparatus; 2) it acts for and on behalf of the state; 3 ) it enjoys state power (has its own particular competence); 4) it has an internal organizational structure; 5) it uses specific forms and methods of activity. The territorial scale of activity and declaration of the legal position of the body in regulatory acts can also be added to this list as optional features (Gabrichidze, 1982: 29; Bakhrakh, 1996: 84-84; Mitskevich, 2016: 138).

All these features of the government bodies are interconnected and interdependent, the bodies have an intrinsic set of the above mentioned distinctive features, their inherent combination. However, the main attribute among them that defines the essence of the government body, its purpose, is the presence of state

\footnotetext{
1 Literally: "In the cases and in conformity with the procedure, stipulated by the federal laws, by the decrees of the President of the Russian Federation and the decisions of the Government of the Russian Federation, by the normative acts of the subjects of the Russian Federation and of the municipal entities, the state bodies, the local self-government bodies, and also the legal entities and the citizens may come out on their behalf upon their special order". (see translation of the Civil Code https://www.wipo.int/edocs/lexdocs/laws/en/ru/ ru083en.pdf) - Translator's note.

2 In English translation of the Civil Code this difference is not so striking, since both Items have the wording "state bodies" with the addition "state power bodies" in Item 1 (see https:// www.wipo.int/edocs/lexdocs/laws/en/ru/ru083en.pdf) Translator's note.
}

powers as regards a certain range of issues, i.e. competence.

In the end, a government body is a part of the state apparatus (an element of a higher level system, i.e. the state), acting for and on behalf of the state and personifying state power.

Despite the existence of common features, the concepts of "government bodies and "state authorities" are not identical. The difference between them lies in the fact that the first embraces bodies belonging to this or that branch of state power, and the second - bodies not attributed to a particular branch of power (Chambers of Accounts, election commissions, prosecutor's office, etc.) (Mitskevich, 2016: 136-137).

As a consequence, it turns out that the legislator has demarcated the cases of implementation of the civil legal capacity of public entities by the considered bodies through the recognition of the government bodies' right to act according to Item 1 of Art. 125 of the Civil Code of the Russian Federation, i.e. generally within their competence, while the state authorities should follow Item 3 of Art. 125 of the Civil Code, in other words, in cases specifically provided for by the legislation and in the presence of a special assignment, yet, the motives of such a decision remain unclear.

In this regard, the question arises about the grounds for such a legislative approach, and the doctrine on it contains several assumptions. Most of the modern researchers are unanimous in the fact that Item 1 of Art. 125 of the Civil Code of the Russian Federation concerns the legal structure of the "body" of a public entity by analogy with the "body" of a legal entity (in the sense of Art. 53 of the Civil Code), and Item 3 of Art. 125 of the Civil Code delineates the relationship of representation, regulated by Chapter 10 of the Civil Code. On balance, it is concluded that in the first case the government bodies are not bound to have civil legal capacity, and in the second case, on the contrary, they should have the status of independent legal entities (Golubtsov, 2019: 70-71; Kravets, 2016: 36-39, etc.). To remove this contradiction, radically different solutions are proposed - from the exclusion of government bodies from Item 3 of Art. 125 of the Civil Code of the Russian Federation (Kravets, 2016: 39) to the legislative 
consolidation of the features of the government bodies' status when they participate in civil relations as legal entities (Golubtsov, 2019: 72).

Having agreed with the general conclusion about the types of legal structures established in Items 1 and 3 of Article 125 of the Civil Code of the Russian Federation, I believe that the answer to the posed question lies in another sphere. Indeed, Item 1 of Art. 125 of the Civil Code of the Russian Federation is about the legal structure of the "body" of a public entity similarly to the "body" of a legal entity, and Item 3 of Art. 125 of the Civil Code classifies the relations of representation, regulated by Chapter 10 of the Civil Code.

Legal grounds for such a conclusion are written in Item 2 of Art. 124 of the Civil Code, by force of which the rules regulating the participation of legal entities in relations governed by civil law are applied to public entities, too, unless otherwise follows from the law or peculiar characteristics of these subjects. According to Item 1 of Article 53 of the Civil Code, a legal entity acquires civil rights and assumes civil obligations through its bodies acting in compliance with the law, other legal acts and charter documents. Since the content of this Item corresponds to the provisions of Item 2 of Art. 124 of the Civil Code, then Item 1 of Art. 53 of the Civil Code can be analogously applied to public entities, which is set out in Item 1 of Art. 125 of the Civil Code. This is explained by the fact that Item 1 of Art. 125 of the Civil Code of the Russian Federation sees government bodies as bodies of the Russian Federation and the subjects of the Russian Federation; it concerns such bodies which due to these circumstances cannot act as independent participants in civil relations, because it is through them the public entity itself enters into civil relations.

Accordingly, Item 3 of Art. 53 of the Civil Code and Item 3 of Art. 125 of the Civil Code refer to the representatives of legal entities and public entities. Therefore, the relations arising between a public entity and such a representative should be covered by Chapter 10 of the Civil Code. But it is necessary to make a reservation that this provision is only for individuals and legal entities, which is quite logical. As for the state authorities, mentioned in Item 3 of Ar- ticle 125 of the Civil Code, those which do not have any connection with the branches of state power cannot have any relations with the public entity due to the non-autonomous nature of the state authorities. In our opinion, Item 3 of Art. 125 of the Civil Code refers to such state authorities which are not supposed to participate in civil relations and which do not have such a right in their competence, therefore, in case of such a need the state may confer special powers on such bodies by issuing a corresponding act. In this sense, there is no contradiction, so, the government bodies and state authorities do not have an independent civil legal capacity, rather they are only capable of realising the legal capacity of a public entity. In this regard, the difference between them is only in the scope of their competence: for the government bodies this eligibility is defined in the act on their status, while state authorities need special granting of power in cases established by law for their participation in civil relations. This granting of power stays within the "special assignment" formula.

Thus, the current civil legislation gives a clear structural model of public entities' participation in private relations, which can be expressed in the following aspects: 1) public legal entities can be recognized as participants of civil relations; the Russian Federation, the subjects of the Russian Federation, as well as municipal entities, are seen separately; 2) they can legally act as independent participants along with individuals and legal entities; 3) public legal entities are not equal to legal entities; 4) civil legal capacity of public legal entities is realised through the actions of government bodies within their general competence (Item 1 of Art. 125 of the Civil Code) or through the actions of the state authorities within the powers specially granted for this very purpose (Item 3 of Art. 125 of the Civil Code).

In any case, the substantial significance is displayed by the powers of a specific state authority, so the relations regulated by the civil legislation are characterized by the provision, due to which the actions of a public legal entity in the sphere of private law (the actions which are not within its competence) do not beget legal consequences for this public entity. It is for this 
reason that judicial practice attaches particular importance to the evaluation of the actions of the Russian Federation bodies and bodies of the RF subjects, since the actions of the authorized body only have legal consequences (cf., for example, Item 4 of the Resolution of the Plenum of the Supreme Court of the Russian Federation "On some issues related to the application of the rules of the Civil Code of the Russian Federation on the limitations of legal claims" No. 43 dated 29.09.2015, and Item 15 of the Resolution of the Plenum of the Supreme Court of the Russian Federation "On the application by the courts of some provisions of the first part of the first section of the Civil Code of the Russian Federation" No. 25 as of 23.06.2015, etc.).

Meanwhile, considering individual cases related to the participation of public entities and individuals in non-contractual obligations, the Constitutional Court of the Russian Federation formulated legal positions that do not fully correspond to the Russian legislative model describing participation of public entities in civil relations.

For instance, in 2017, during the case following the complaint of citizen A.N. Dubovets, the Constitutional Court of the Russian Federation adopted the widely known Decree No. 16-P of 22.06.2017, according to which there appeared a special exception to the rules of Art. 302 of the Civil Code on vindication of property in relation to the situation when the public entity claims the reclamation of property from unlawful possession of a bona fide purchaser an individual.

During the formation of the legal conclusion for this case the Constitutional Court of the Russian Federation paid close attention (inter alia) to the assessment of a condition provided by Art. 302 of the Civil Code, namely the reclamation of property from the possession of the owner beyond one's will. In addition, the Constitutional Court of the Russian Federation essentially analyzed the procedure for participation of public entities in civil relations by the example of the institution of escheat.

In particular, it was proposed to take into account and analyze two points when settling the respective disputes: "the fact of state registration of the ownership right to the dwelling premises for the person who had no right to alienate it, and the nature of actions (inaction) of the public owner personified by the authorized bodies that are entrusted with the competence to register title to escheated property and dispose of it".

In the context of the issue under consideration, the dual position of the Constitutional Court of the Russian Federation on the powers of bodies acting on behalf of the state raises concern. On the one hand, the court states unequivocally that the loss of the escheated intangible property by public entity may be caused by "inaction of relevant bodies which have not formalized the ownership right to it within a reasonable period of time, which to a certain extent creates prerequisites for its loss, including through withdrawal of the property from the possession of the public owner as a result of unlawful actions of third parties". The RF Constitutional Court uses the term "authorized bodies" to name this type of bodies without giving any other options.

But there is a completely different situation when the court assesses the fact of state registration of ownership under forged documents as regards a third party claiming escheated dwelling premises. The Constitutional Court of the Russian Federation has already criticized the position of the courts that do not consider "expression of the will of a public legal entity aimed at withdrawal of intangible property from the possession of a public owner, the act of state registration of the right to this property (although it is this act that confirms the legality of the transaction made by the originally unauthorized alienator of intangible property with a third party) as permissive, as the basis for the alienator's registration as the owner of this property and, consequently, the justified legality of the transaction.

Hereby, the Constitutional Court of the Russian Federation comes to the conclusion that "the state, represented by legally authorized bodies and officials acting during the procedure of state registration of rights to intangible property, confirms the legality of a transaction on withdrawal of intangible property".

As a result, it turns out that, in the opinion of the RF Constitutional Court, the reg- 
istration body that exercises the authority to perform registration actions within its competence, established by a regulatory legal act, and which does not have the authority to dispose of escheated property owned by a public entity, nevertheless, authorizes the transactions on withdrawal of such real estate objects. Putting it another way, the body that registered the ownership of a third party on the basis of forged documents in such a manner expressed the will of the public entity to alienate this property from the possession of the latter. In this case, there is a confusion of norms of public (registration) and private law, since it is impossible to identify the actions of a state authority to perform public functions as actions for disposal of a specific public property, especially in a situation when the state authority has not been entitled to disposal of property of a public legal entity. It is obvious that this interpretation does violate the provisions of Art. 125 of the Civil Code and the legislative model of public entities' participation in civil relations.

What is more, one should pay heed to another essential fact left without proper legal assessment by the Constitutional Court of the Russian Federation. As it follows from the analyzed resolution of the Constitutional Court of the Russian Federation, the plaintiff in the case of citizen A.N. Dubovets was Moscow itself, i.e. the subject of the Russian Federation, which had got the disputable dwelling premises as escheated property. The right of ownership of this property was registered in the Unified State Register of Property by the authorized body, which is a federal government body, i.e. a body of the Russian Federation. Eventually, the court concluded that the dwelling premises was no longer the property of the subject of the Russian Federation as a result of registration actions by the body implementing legal capacity of another public entity - the Russian Federation. The court did not provide any arguments justifying such interpretation of the law. At the same time, public entities, from the point of view of the Constitution of the Russian Federation and from the point of view of the Civil Code of the Russian Federation, are independent and equal participants of public and private relations, therefore, as a general rule, the actions of one public legal entity are not able to generate legal consequences for another public legal entity unless it is specified either in the law or in the contract. Thus, the legal position in the case considered by the Constitutional Court of the Russian Federation is controversial and requires further investigation.

The next act of the Constitutional Court of the Russian Federation, which is of interest in the context of the analysed issue, is the Resolution of the Constitutional Court of the Russian Federation No. 39-P dated 08.12.2017. When forming the legal conclusion on the possibility of civil liability of an individual for failure to fulfill tax obligations by a legal entity, the court separately considered the issue of the authority of tax bodies to apply to the court with a claim for compensation for damages in such cases.

Thereat, the RF Constitutional Court, having assessed Article 31 of the RF Tax Code and the provisions of the RF Law "On Tax Authorities of the Russian Federation", stated the absence of a direct reference to the right of tax bodies to apply to court for compensation of damages based on Article 1064 of the RF Civil Code. In other words, the court found that the tax bodies had no such authority within their competence as established by the acts determining the status of these bodies. At the same time, this circumstance did not prevent the RF Constitutional Court, which followed the RF Supreme Court in its decision, from coming to the conclusion that such right still belongs to the tax bodies, as in this case they do not hold citizens to account using their powers; they only express the will of the affected public legal entity, addressing the court with the relevant claims on its behalf.

Taking into account that the current procedural legislation unambiguously defines the prosecutorial authorities as authorized subjects with the right to apply to court with claims for protection of property interests of public entities in all categories of cases, there would be a violation of the Art. 125 of the Civil Code if the list of such authorities includes tax bodies when there are no legal grounds for such a solution. 


\section{Conclusion}

The present legislative model of participation of public legal entities in civil relations does not provide any exceptions for non-contractual obligations arising between the state and individuals. On the contrary, the legislators have been consistent in addressing the issue of which bodies of the state are able to ensure the civil legal capacity of the latter and under what conditions. Amendment of the above model by the Constitutional Court of the Russian Federation via expanding the list of bodies capable of creating legal consequences for public entities, without taking into account the scope of their competence, as well as differences between federal bodies and state authorities of the subjects of the Russian Federation, is considered untimely and requires further thorough study and elaboration.

\section{References}

Bahrah, D.N. (1996). Administrativnoe pravo: Uchebnik. Chast'obshchaia [Administrative law: Textbook. Common part]. Moscow, BEK, 330 p.

Gabrichidze, B.N. (1982). Konstitutsionnyi status organov sovetskogo gosudarstva [Constitutional status of the bodies of the Soviet state]. Moscow, $184 \mathrm{p}$.

Golubtsov, V.G. (2019). Rossiiskaia Federatsiia kak sub'ekt grazhdanskogo prava [Russian Federation as a subject of civil law]. Moscow, "Statut", 272 p.

Kravets, V.D. (2016). Grazhdansko-pravovoi status publichnykh iuridicheskikh lits: monografiia [Civil legal status of public legal entities: Monograph]. Moscow, "Prospekt", 192 p.

Mitskevich, L.A. (2016). Ocherki teorii administrativnogo prava: sovremennoe napolnenie: monografiia [Essays on the theory of administrative law: modern content: Monograph]. Moscow, "Prospekt", 296 p. 


\title{
К вопросу о модели участия публичных образований \\ в гражданских отношениях \\ в свете правовых позиций Конституционного суда РФ
}

\section{И.С. Богданова}

Сибирский федеральный университет

Российская Федерачия, Красноярск

\begin{abstract}
Аннотация. Статья посвящена проблеме изменения Конституционным судом РФ модели участия публично-правовых образований в гражданских отношениях на примере внедоговорных обязательств, возникающих между государством и физическими лицами. С этой целью проведено исследование законодательной модели участия государства в частных отношениях, закрепленной в ст. 2, 125 Гражданского кодекса РФ, и правовых позиций Конституционного суда РФ, сформированных в Постановлениях КС РФ от 22.06.2017 № 16-П и от 08.12.2017 № 39-П. В результате автор приходит к выводу о том, что действующая легальная модель участия публично-правовых образований в гражданских отношениях не предусматривает каких-либо исключений для внедоговорных обязательств, возникающих между государством и физическими лицами. Наоборот, законодатель последователен в решении вопроса о том, какие органы государства и при каких условиях способны реализовать гражданскую правосубъектность последнего. Изменение указанной модели Конституционным судом РФ посредством расширения перечня органов, способных создавать для публичных образований правовые последствия, без учета объема их компетенции, а также различий между федеральными органами власти и органами государственной власти субъектов РФ является преждевременным и требует тщательного изучения и проработки.
\end{abstract}

Ключевые слова: публично-правовые образования, орган государственной власти, государственный орган, гражданская правосубъектность государства, модель участия, гражданские отношения, регистрирующие органы, налоговые органы.

Научная специальность: 12.00 .00 - юридические науки. 